УДК: 338.486: 379.8

https://doi.org/10.33296/2707-0255-9(17)-21

http://orcid.org/0000-0001-9502-9604*

БЕЗКОРОВАЙНА ЛАРИСА*

Доктор педагогічних наук, професор кафедри туризму та готельно-ресторанної справи Запорізький національний університет, м. Запоріжжя

КОСОВЩУК АНГЕЛІНА Магістр спеціальності туризм Запорізький національний університет, м. Запоріжжя

\title{
ЗАРУБІЖНИЙ ДОСВІД УПРАВЛІННЯ ТА ОРГАНІЗАЦІЇ СИСТЕМИ ОСВІТНЬОЇ ДІЯЛЬНОСТІ МАЙБУТНІХ ФАХІВЦІВ ТУРИСТИЧНОГО НАПРЯМУ
}

Анотація. У статті авторами здійснено дослідження зарубіжного досвіду управління та організації професійної підготовки майбутніх фахівців із туристичного спрямування в закладах вищої освіти. Акцентовано увагу на сучасних тенденція до підвищення якості світової професійної туристичної освіти завдяки інтеграції, диверсифікації, уніфікації, управлінню та організації навчального процесу. Стрімке зростання попиту суспільства на нові туристичні послуги підвищує вимоги до якісної підготовки конкурентоспроможних фахівців для туристичної галузі, які володіють системою професійно важливих знань, умінь, навичок відповідно до сучасних потреб світового суспільства. Тому ефективне управління системою підготовки фахівців туристичної індустрії є однією 3 нагальних цілей світових держав. В статті опрацьовано науковий досвід провідних фахівців із організації та управління процесом підготовки фахівців у закладах вищої освіти в таких аспектах, як: неперервна професійна освіта, педагогічні технології, розвиток професійної компетентності та розвиток особистості фахівця в ході професійної підготовки, а також питання інформаційного забезпечення та моделювання освітнього процесу. Розглянуто положення міжнародних конвенцій, декларацій та програм із питань освіти в межах ЮНЕСКО, що мають велике значення у становленні й сталому розвиткові світової туристичної вищої освіти. Підкреслено на необхідності зберігати, зміцнювати та поширювати головні завдання, цінності вищої освіти, зокрема, стосовно iï вкладу в сталий розвиток і вдосконалення суспільства для
(C) Українська інженерно-педагогічна академія
(C) ГО «Школа адаптивного управління соціально-педагогічними системами»
(C) Безкоровайна Л.
(C) Косовщук А. 
забезпечення інтелектуальної незалежності, створення й просування знань, підготовки та формування відповідальних громадян і кваліфікованих фахівців, без яких неможливо досягти економічного, соціального, культурного та політичного прогресу будь-якої нації.

Ключові слова: управління, організація освітньої діяльності, професійна підготовка, туризм, індустрія туризму, туризмознавство, фахівець з туризму.

Вступ. Сучасний туризм є одним із провідних видів господарської діяльності більшості країни світу, що швидко оновлюється, інтегруючись 3 іншими сферами. Саме тому актуальним питанням сучасності $\epsilon$ всебічне дослідження туристичної галузі. Це ставить нові завдання перед туризмознавством як провідною галуззю наукового знання й формує нові вимоги до професійної підготовки фахівців з туризмознавства, спрямованої на забезпечення сформованості світоглядного, інноваційного, наукового мислення особистості фахівця, готовності до професійного вдосконалення впродовж життя [3].

Аналіз досліджень і публікацій. Проблема професійної підготовки майбутніх фахівців з туризмознавства в закладах вищої освіти знайшла своє відображення при вирішенні широкого кола теоретичних і практичних питань у працях, спрямованих переважно на дослідження: філософії освіти (В.П. Андрущенко, В.О. Огнев’юк та ін.); неперервної професійної освіти (С.У. Гончаренко, Н.Г. Ничкало та ін.), розвитку особистості фахівця в ході професійної підготовки (В.В. Рибалка, Л.П. Сущенко та ін.); професійної компетентності фахівця (О.І. Гура, Дж. Равен та ін.); педагогічної технології (В.П. Беспалько, Г.К. Селевко та ін.); інформаційного забезпечення освіти (В.Ю. Биков, Р.М. Вернидуб, В.К. Вінник, Р.С. Гуревич, М.Ю. Кадемія, Л.М. Хуторська та ін.); моделювання в освіті (О.О. Горбачов, К.С. Тарарієва, Б.А. Франкфурт та ін.) [3].

На увагу заслуговують праці, присвячені різним питанням туризму, вітчизняних (О.О. Бейдик, О.О. Любіцева, М.П. Мальська та ін.) і зарубіжних
(C) Українська інженерно-педагогічна академія
(C) ГО «Школа адаптивного управління соціально-педагогічними системами»
(C) Безкоровайна Л.
(C) Косовщук А. 
(К. Аннару, Дж. Боуен, Д.Л. Едгель ст., І.В. Зорін, Т.П. Кавєріна, Т.П. Квартальнов, Дж. Майкенз, Р. Макінтош, Б. Рітчі, Н. аль-Сааді та ін.) учених [3].

Формування цілей статті. Мета нашої статті полягає у дослідженні зарубіжного досвіду управління та організації системи підготовки майбутніх фахівців туристичного напряму в закладах вищої освіти.

Виклад основного матеріалу. На сьогодні у світовій професійній туристичній освіті спостерігаються процеси, спрямовані на підвищення іï якості завдяки інтеграції, диверсифікації та уніфікації. Це зумовлено стрімким зростанням попиту суспільства на нові туристичні послуги. Внаслідок цього, підвищуються вимоги до якісної, всебічно збалансованої підготовки конкурентоспроможних фахівців для туристичної галузі, які володіють системою професійно важливих знань, умінь, навичок та особистих якостей відповідно до сучасних потреб світового суспільства. Тому, гармонізація підготовки фахівців туристичної індустрії є однією з нагальних цілей світових держав та країн Європейського союзу.

Зазначимо, що міжнародний туризм відіграє значну роль у взаємодії і взаємозбагачення культур, соціальної та політичної інтеграції, дипломатичної уніфікації та культурного співробітництва. Велике значення у становленні й сталому розвитку світової туристичної вищої освіти мають рішення міжнародних конвенцій, декларацій та програм 3 питань освіти в межах ЮНЕСКО. Так, у конвенції про визнання кваліфікацій вищої освіти в Європейському регіоні (м. Лісабон, 1997 р.) містяться основні принципи 3 оцінки кваліфікацій та визначається компетенція державних органів [1].

У «Всесвітній декларації про вищу освіту для ХХІ століття: підходи і практичні заходи» (м. Париж, 1998 р.) стверджується, що необхідно зберігати, зміцнювати, поширювати головні завдання, цінності вищої освіти, зокрема, стосовно iї вкладу в сталий розвиток і вдосконалення суспільства для

\footnotetext{
(C) Українська інженерно-педагогічна академія

(C) ГО «Школа адаптивного управління соціально-педагогічними системами»

(C) Безкоровайна Л.

(C) Косовщук А.
} 
забезпечення інтелектуальної незалежності, створення й просування знань, підготовки та формування відповідальних громадян і кваліфікованих фахівців, без яких неможливо досягти економічного, соціального, культурного, політичного прогресу нації [1]. Цим документом встановлено статті, згідно яких вища освіта має забезпечити:

1) поширення освіти, підготовки кадрів, проведення наукових досліджень:

- підготовку висококваліфікованих випускників, здатних задовольняти потреби в усіх сферах діяльності шляхом надання можливості отримувати відповідні кваліфікації, що поєднують знання й навички високого рівня, 3 використанням курсів і навчальних програм, що постійно адаптуються до потреб суспільства;

- відкритий простір для здобуття вищої освіти й навчання протягом усього життя, можливості для індивідуального розвитку і соціальної мобільності;

- просування, створення, поширення знань шляхом дослідної діяльності, створення умов для культурного, соціального, економічного розвитку суспільства шляхом заохочення й розвитку природничих, технологічних розвідок, досліджень у сфері соціальних і гуманітарних наук;

- допомогу, порозуміння, інтерпретацію, збереження, поширення, розвиток національної, регіональної, міжнародної, історичної культури в умовах іï плюралізму та різноманітності; сприяння захисту, зміцнення суспільних цінностей, поширення гуманізму в світі; розвиток, вдосконалення освіти на всіх рівнях, у тому числі, шляхом підготовки викладачів;

2) етичної ролі:

- збереження і поширення викладачами своїх функцій з дотриманням наукової, інтелектуальної етики та вимогливості;

3) справедливості доступу:
(C) Українська інженерно-педагогічна академія
(C) ГО «Школа адаптивного управління соціально-педагогічними системами»
(C) Безкоровайна Л.
(C) Косовщук А. 
- доступ до вищої освіти на основі визначення здібностей, зусиль, наполегливості тих, хто бажає іiі отримати, зі збереженням можливості використання набутих навичок у будь-який час протягом життя;

4) просування знань шляхом проведення наукових досліджень у галузях природничих, гуманітарних наук і мистецтва та поширення їх результатів:

- стимулювання трансдисциплінарності, міждисциплінарності, новаторства програм, передбачуючи довгострокову перспективу, орієнтовану на досягнення забезпечення потреб у соціальній і культурній сферах;

- підготовку, підтримку учасників наукових досліджень; активізацію досліджень в усіх дисциплінах усіх наук, галузей знань у межах національної, регіональної, міжнародної політики щодо наукових досліджень і розробок;

5) довгострокової адекватності:

- відповідність очікуванням суспільства, що заснована на соціальних цілях і потребах, включаючи поважне ставлення до культури і охорони навколишнього середовища;

- доступ до загальної та спеціальної освіти, спрямованої на певну професійну діяльність, приділяючи пильну увагу розвитку навичок i здібностей, оскільки ці освіти готують особу до життя в різних мінливих умовах;

6) зміцнення співпраці зі світом праці, аналізу і прогнозування суспільних потреб:

- зміцнення, оновлення зв'язку між вищою освітою, світом праці, іншими секторами суспільства шляхом активного суміщення роботи 3 навчанням, обмінів між світом праці та закладами вищої освіти, міцного зв'язку навчальних програм 3 професійною діяльністю, спільного забезпечення розвитку й оцінки навчального процесу, об'єднання теорії та практики на робочих місцях, врахування сучасних світових тенденцій праці, реагування на потреби в робочій силі;

\footnotetext{
(C) Українська інженерно-педагогічна академія

(C) ГО «Школа адаптивного управління соціально-педагогічними системами»

(C) Безкоровайна Л.

(C) Косовщук А.
} 
7) новаторських підходів в освіті: критичного мислення і творчості:

- орієнтацію на виховання особистості студента, добре проінформованої, глибоко мотивованої, відповідальної, компетентної, ініціативної; здатної до комунікації, колективної праці; творчого, критичного, незалежного мислення, аналізу, пошуку й вирішення проблем суспільства, шляхом нової парадигми змісту, методів, практики, засобів, педагогічних і дидактичних підходів, навчально-методичних матеріалів, методів тестування, заснованих на оновленні зв'язків та партнерства 3 суспільством, 3 метою забезпечення зайнятості випускників, як творців робочих місць;

8) викладачів закладів вищої освіти як основних дійових осіб:

- проведення наукових досліджень, оновлення i вдосконалення педагогічних навичок викладачів на основі міжнародного досвіду, програм підвищення кваліфікації, що стимулюють безперервну освіту, постійне новаторство методів викладання i навчання, 3 метою спрямування ролі викладача, як джерела знань, на прищеплення студентам ініціативності та умінь навчатись [1].

Узагальнюючи зазначене, відмітимо, що впровадження в освітній процес зарубіжних закладів вищої освіти, що здійснюють підготовку фахівців 3 туризмознавства, наведених рекомендацій щодо поліпшення якості освіти, забезпечує ефективність підготовки конкурентоспроможних фахівців, здатних задовольняти потреби в діяльності туристичної галузі відповідно до запитів світового суспільства.

Підкреслимо, що однією 3 основних цілей ЮНЕСКО є заохочення і розвиток народної освіти, а також встановлення співробітництва народів 3 метою поступового досягнення ідеалу доступності освіти для всіх, незалежно від раси, статі, будь-яких соціально-економічних відмінностей. Вона вказує на методи освіти, які найбільш відповідні підготовці дітей усього світу до усвідомлення відповідальності вільної людини [1, ст. 1 Статуту].

\footnotetext{
(C) Українська інженерно-педагогічна академія

(C) ГО «Школа адаптивного управління соціально-педагогічними системами»

(C) Безкоровайна Л.

(C) Косовщук А.
} 
В той же час, роль ЮНВТО, як міжнародної міжурядової організації в галузі туризму, що $є$ агенцією ООН та відповідає за загальнодоступність туризму й перспективний розвиток туристичної галузі, полягає у сприянні розвитку туристичної діяльності, що забезпечує зміцнення міжнародних зв'язків, досягнення взаєморозуміння між народами різних країн, розширенні торгового партнерства між державами [2].

Зазначити, що програма TedQual $\epsilon$ системою сертифікації навчальних закладів, у яких здійснюється підготовка фахівців з туристичної сфери, на добровільних засадах, що сприяє розвиткові туристичної освіти, підготовці кваліфікованих кадрів, а також вдосконалення науково-дослідних програм в цій галузі [2]. Тож програма TedQual спрямована на полегшення постійного вдосконалення туристичної освіти, навчально-дослідних програм шляхом визначення комплексу мінімальних стандартів якості туристичної освіти. 3 цією метою система враховує п’ять напрямів аналізу, що оцінюють внутрішні та зовнішні аспекти програми:

- когерентність плану досліджень;

- інфраструктура і педагогічна підтримка;

- політика, інструменти та механізми підтримки адміністративного управління;

- існування прозорих механізмів відбору викладачів і сприятливих умов для їх професійного розвитку;

- актуальність змісту програми навчання потребам туристичного сектору [2].

Відзначено, що сертифікація здійснюється відповідно до запиту будьякого закладу, що здійснює підготовку фахівців туристичного напряму, навчальною або дослідною установою, що має один або декілька постійних туристичних програм. Система сертифікує програми, які мають хоча б один випускний клас.

\footnotetext{
(ㄱ Українська інженерно-педагогічна академія

(ㄷ) ГО «Школа адаптивного управління соціально-педагогічними системами»

(c) Безкоровайна Л.

() Косовщук А.
} 
Визначено, що з метою сприяння розвитку туристичної освіти, підготовки кваліфікованих кадрів, забезпечення постійного вдосконалення туристичної освіти та навчально-дослідних програм шляхом визначення комплексу мінімальних стандартів якості туристичної освіти, здійснюється програма TedQual, що є системою сертифікації навчальних закладів, які реалізують підготовку фахівців з туризму [3].

Висновок. Визначено такі вимоги вищої туристичної освіти, а саме: оновлення навчальних програм відповідно до соціальних потреб; розробка міжнародних стандартів; науково-дослідна робота, реалізація проектів 3 розвитку туризму; накопичення академічних результатів; забезпечення ступеневості, безперервності освіти; активізація новаторства викладачів, викладання поширеними мовами світу; орієнтація на всебічний професійний та особистісний розвиток студента, що передбачає формування мотивації його навчально-професійної діяльності, ініціативності, творчості, здатності до колективної праці, партнерства.

Постійний розвиток і вдосконалення туристичної освіти, навчальнодослідних програм забезпечує програма TedQual, що є системою Всесвітньої туристичної організації для сертифікації закладів освіти, які здійснюють підготовку фахівців з туризму.

Перспективи подальших досліджень. Перспективними напрямами вбачаються дослідження інших аспектів управління проєктною діяльністю майбутніх фахівців з туризму в закладах вищої освіти.

\section{СПИСОК ВИКОРИСТАНИХ ДЖЕРЕЛ}

1. United Nations Educational, Scientific and Cultural Organization. UNESCO. URL: http://www.unesco.org/new/en/unesco/resources/onlinematerials/publications/unesdoc-database/

2. World Tourism Organization.

UNWTO.

URL: http://media.unwto.org/ru/annual-reports

\footnotetext{
(C) Українська інженерно-педагогічна академія

(C) ГО «Школа адаптивного управління соціально-педагогічними системами»

(C) Безкоровайна Л.

(C) Косовщук А.
} 
3. Безкоровайна Л. Теоретичні і методичні засади професійної підготовки майбутніх фахівців з туризмознавства у вищих навчальних закладах: дис. ... дра пед. наук: 13.00.04. Запоріжжя, 2018. 713 с.

\title{
REFERENCES
}

1. United Nations Educational, Scientific and Cultural Organization. UNESCO. URL: http://www.unesco.org/new/en/unesco/resources/onlinematerials/publications/unesdoc-database/

2. World Tourism Organization. UNWTO. URL: http://media.unwto.org/ru/annual-reports

3. Bezkorovaina L. Theoretical and methodical principles of professional training of future specialists in tourism in the field of higher education: dis. ... Dr. ped. Science: 13.00.04. Zaporozhye, 2018. 713 p.

\author{
БЕСКОРОВАЙНАЯ ЛАРИСА \\ Доктор педагогических наук, \\ профессор кафедры туризма и \\ гостинично-ресторанного дела \\ Запорожский национальный \\ университет,. Запорожье \\ КОСОВЩУК АНГЕЛИНА \\ Магистр специальности туризм \\ Запорожский национальный \\ университет,. Запорожье
}

\section{ЗАРУБЕЖНЫЙ ОПЫТ УПРАВЛЕНИЯ И ОРГАНИЗАЦИИ СИСТЕМЫ ОБРАЗОВАТЕЛЬНОЙ ДЕЯТЕЛЬНОСТИ БУДУЩИХ СПЕЦИАЛИСТОВ ТУРИСТИЧЕСКОГО НАПРАВЛЕНИЯ}

Аннотация. В статье авторами проведено исследование зарубежного опыта управления и организации профессиональной подготовки будущих специалистов туристического направления в учреждениях высшего образования. Акцентировано внимание на современных тенденциях к повышению качества мирового профессионального туристического образования благодаря интеграции, диверсификации, унификации, управлению и организации учебного процесса. Стремительный рост спроса общества на новые туристические услуги повышает требования к качественной подготовке конкурентоспособных специалистов для туристической отрасли, владеющих

\footnotetext{
(C) Українська інженерно-педагогічна академія

(C) ГО «Школа адаптивного управління соціально-педагогічними системами»

(C) Безкоровайна Л.

(C) Косовщук А.
} 
системой профессионально важных знаний, умений, навыков в соответствии с современными потребностями мирового сообщества. Поэтому эффективное управление системой подготовки специалистов туристической индустрии является одной из насущных целей мировых держав. В статье представлен научный опыт ведущих специалистов по организации и управления процессом подготовки специалистов в учреждениях высшего образования в таких аспектах, как: непрерывное профессиональное образование, педагогические технологии, развитие профессиональной компетентности и развитие личности специалиста в ходе профессиональной подготовки, а также вопросы информационного обеспечения и моделирования образовательного процесса. Рассмотреные положения международных конвенций, деклараций и программ по вопросам образования в пределах ЮНЕСКО имеют большое значение в становлении и устойчивом развитии мирового туристического высшего образования. Подчеркнута необходимость сохранять, укреплять и распространять главные задачи, ценности высшего образования, в частности по его вкладу в устойчивое развитие и совершенствование общества для обеспечения интеллектуальной независимости, создания и продвижения знаний, подготовки и формирования ответственных граждан и квалифицированных специалистов, без которых невозможно достичь экономического , социального, культурного и политического прогресса любой нации.

Ключевые слова: управление, организация образовательной деятельности, профессиональная подготовка, туризм, индустрия туризма, туризмоведение, специалист по туризму.

\author{
BESKOROVAYNAY LARISA \\ Doctor of Pedagogy, Professor \\ Department of Tourism and \\ hotel and restaurant business \\ Zaporizhzhya National University \\ Zaporozhye city \\ KOSOVSHCHUK ANGHELINA \\ Master's in Tourism \\ Zaporizhzhya National University \\ Zaporozhye city
}

\title{
FOREIGN EXPERIENCE IN MANAGEMENT AND ORGANIZATION OF THE SYSTEM OF EDUCATIONAL ACTIVITIES OF FUTURE SPECIALISTS OF THE TOURISM DESIGN
}
(C) Українська інженерно-педагогічна академія
(C) ГО «Школа адаптивного управління соціально-педагогічними системами»
(C) Безкоровайна Л.
(C) Косовщук А. 
Abstract. In the article the authors carried out a study of foreign experience in the management and organization of professional training of future specialists in tourism in higher education. Emphasis is placed on modern tendencies to improve the quality of world professional tourism education through integration, diversification, unification, management and organization of the educational process. The rapid growth of public demand for new tourism services increases the requirements for quality training of competitive professionals in the tourism industry, who have a system of professionally important knowledge, skills, abilities in accordance with the modern needs of world society. Therefore, effective management of the system of training specialists in the tourism industry is one of the urgent goals of the world. The article deals with the scientific experience of leading specialists in the organization and management of the training process in higher education institutions in such aspects as: continuing professional education, pedagogical technologies, development of professional competence and personality development during training, as well as information support and modeling educational process. The provisions of international conventions, declarations and programs on education within UNESCO, which are of great importance in the formation and sustainable development of world tourism higher education, are considered. Emphasis is placed on the need to preserve, strengthen and disseminate the main objectives and values of higher education, in particular its contribution to sustainable development and improvement of society to ensure intellectual independence, create and promote knowledge, train and train responsible citizens and skilled professionals., social, cultural and political progress of any nation.

Key words: management, organization of educational activities, professional training, tourism, tourism industry, tourism studies, tourism specialist.

\footnotetext{
(C) Українська інженерно-педагогічна академія

(C) ГО «Школа адаптивного управління соціально-педагогічними системами»

(C) Безкоровайна Л.

(C) Косовщук А.
} 